1

2

3

\title{
Geothermal energy in sedimentary basins in the UK
}

\author{
$4 \quad$ ae-mail: jpbu@,bgs.ac.uk \\ 5 tel : +441159363440 \\ 6 Fax : +44 1159363200 \\ Jon Busby ${ }^{1 a}$, \\ ${ }^{1}$ British Geological Survey, Keyworth, Nottingham, NG12 5GG, UK
}

7 Abstract

8 Deep onshore Mesozoic basins have favourable geothermal aquifers at depth comprising 9 basal Permo-Triassic sandstones. The principal basins are the Wessex and Worcester 10 (southern England), Cheshire (northwest England), Eastern England, Larne and Lough Neagh 11 (Northern Ireland). Measured temperatures are up to $80{ }^{\circ} \mathrm{C}$ and could reach $100{ }^{\circ} \mathrm{C}$ in the 12 deepest parts of some of the basins. Porosity and permeability data from depth are limited, 13 but values high enough to allow adequate yields have been measured in many of the basins.

14 Productive sandstones vary from a few tens of metres to hundreds of metres thick resulting in 15 productive transmissivities. The estimated heat in place (Inferred Geothermal Resource) has been calculated as $201 \times 10^{18}$ to $328 \times 10^{18} \mathrm{~J}$. New heat demand maps illustrate that many of the centres of high heat use are coincident with Upper Palaeozoic basins. Within the Carboniferous and Devonian there are thick sequences of deeply buried arenaceous deposits. Some productive local aquifers occur at shallow depth, but most depend on fissure flow that is anticipated to diminish rapidly with depth. The exception may be the Carboniferous Limestone where warm springs and a pronounced thermal anomaly in eastern England demonstrate groundwater flow at depth, possibly along pathways of many kilometers. 
25 Keywords: Thermal systems, UK, Geothermal resources, Sedimentary basins, Renewable

26 heat 


\section{Introduction}

This paper reviews the direct-use geothermal resources that are known and have been assessed in the United Kingdom (UK). There is an increasing requirement for renewable energy to displace fossil fuels (DECC, 2009; 2011) for both electricity generation and heat. Direct-use geothermal resources have been little utilised in meeting the UK's renewable heat requirements. The review concentrates on the thermal resource and the hydrogeology, but does not consider aspects of utilization such as the geochemistry of the groundwater. These resources comprise aquifers at sufficient depth that temperatures are high enough for exploitation without a heat pump. They are frequently referred to as hot sedimentary/saline aquifers (HSA). The possibility of using these HSA resources for electricity generation with a binary cycle is not considered here, mainly because there are very limited possibilities onshore UK (Jackson, 2012). The definitive study of UK HSA resources was undertaken as part of the Geothermal Energy Programme that was funded by the UK government and the European Commission and ran from 1977-1994 (Downing and Gray, 1986a). This study was able to appraise the information available from hydrocarbon exploration and funded the drilling of four, deep geothermal boreholes. However at the end of the Programme the only development was the utilization of one of the geothermal boreholes in the city of Southampton to provide heat to a district heating scheme (Barker et al., 2000).

It should be noted that in geothermal studies the units of permeability and transmissivity are generally quoted as Darcies and Darcy metres respectively which are independent of fluid properties. S.I. units are used here and in order to maintain independence of fluid properties, 
56 intrinsic permeability and intrinsic transmissivity with units of $\mathrm{m}^{2}$ and $\mathrm{m}^{3}$ respectively are used (see Singhal and Gupta, 2010).

\section{Heat flow}

The United Kingdom is situated on the stable foreland of Europe and is devoid of active volcanism and high heat flows that result from tectonic activity. Enhanced heat flow will only occur if there is heat production within the crust or over regions associated with a shallower Moho. The majority of the enhanced heat production is associated with high-heat-producing granites that due to their buoyancy often provide the blocks to the sedimentary basins, especially during Carboniferous times (Leeder, 1982; Bott et al., 1984; Fraser et al., 1990). Pronounced crustal thinning (Moho depths less than $25 \mathrm{~km}$ ) is observed offshore beneath the central and northern North Sea grabens and the basins of the northwest margin. Moho depths are at their greatest onshore (greater than $32 \mathrm{~km}$ ) with the possible exception of northwest Scotland where depths of 27-30 km might be found (Chadwick and Pharaoh, 1998). The heat flow map of the UK is shown in Figure 1 (Lee et al., 1987; Downing and Gray, 1986a, b; Rollin, 1995; Rollin et al., 1995; Barker et al., 2000). It comprises 212 heat flow measurements augmented by 504 heat flow estimates. Heat flow is calculated from Fourier's Law of heat conduction:

$$
q=-\lambda \operatorname{grad} T
$$

where $q=$ heat flow $\left(\mathrm{W} \mathrm{m}{ }^{-2}\right), \lambda=$ thermal conductivity $\left(\mathrm{W} \mathrm{m}^{-1} \mathrm{~K}^{-1}\right)$ and $\operatorname{grad} T=$ temperature gradient $\left(\mathrm{K} \mathrm{m}^{-1}\right)$. Heat flow is derived by combining equilibrium temperature gradients with measured thermal conductivities from the geological strata over which the equilibrium temperature gradients were measured (a thermal conductivity log). In the case of measured heat flow there are a suite of temperature gradients and associated thermal conductivities down the borehole and these can be combined using the step-integrated heat flow equation of 
Bullard (1939). The relationship between the thermal resistance $R$ and the temperature $T$ is linear for conductive, steady-state vertical heat flow with no internal heat production, i.e.

$$
T_{z}=T_{o}+Q \sum_{i}\left(\frac{\Delta z_{i}}{\lambda_{i}}\right)
$$

Where $R=\sum_{i}\left(\frac{\Delta z_{i}}{\lambda_{i}}\right), \lambda_{\mathrm{i}}$ is the thermal conductivity of the ith layer of thickness $\Delta z_{\mathrm{i}}, T_{\mathrm{o}}$ is the mean ground surface temperature and $Q$ is the heat flow. Bullard resistance plots were used for the 212 heat flow measurements. For estimated heat flow the thermal conductivities have to be assumed (Rollin, 1995) and there is usually only a single temperature gradient. These were calculated directly from Fourier's Law. Inevitably estimated heat flows are far less reliable than measured. There is a fairly uniform background field of around $52 \mathrm{~mW} \mathrm{~m}$. Areas of increased heat flow are associated with the radiogenic granites in southwestern England (mean value of $117 \mathrm{~mW} \mathrm{~m}^{-2}$ ) and the buried granites of northern England. Values are also above the regional background over the batholith in the Eastern Highlands of Scotland. The average UK geothermal gradient is $26^{\circ} \mathrm{C} \mathrm{km}^{-1}$, but locally it can exceed $35^{\circ} \mathrm{C}$ $\mathrm{km}^{-1}$. Hence, over onshore sedimentary basins there is an expectation that temperatures at $3000 \mathrm{~m}$ depth would be around $88^{\circ} \mathrm{C}$.

\section{Mesozoic sedimentary basins}

The basin summaries below are compiled from Downing and Gray (19886a, b), Barker et al. (2000), Rollin et al. (1995), Bennett (1980), Downing et al. (1982), Mitchell (2004) and Reay and Kelly (2010).

Within the UK the greatest likelihood of finding permeable rocks at sufficient depth for temperatures suitable for direct use applications are in the post-Carboniferous sedimentary basins. Although referred to as Mesozoic basins, the basal sediments are Permian. The aquifers with the greatest potential are the Permo-Triassic sandstones, which are found in 
several basins at depths greater than $1500 \mathrm{~m}$. Within the basins the first deposits to be laid down were coarse breccias and sandstones that are concentrated along the basin margins, but occur impersistently and variably over the whole basin. The breccias are overlain by coarsegrained, well-sorted, cross-bedded sandstones of aeolian origin, which merge into water-laid deposits. These sediments can attain thicknesses of several hundred metres. These Permian breccias and sandstones are overlain by Upper Permian limestones, dolomites and evaporates that often form a low permeability base to the overlying Triassic aquifers. The Triassic period saw a return to a continental environment where thick clastic deposits accumulated that are largely of fluviatile origin, but locally wind-blown deposits, marls and breccias occur. These sandstones are collectively referred to as the Sherwood Sandstone Group. A number of cycles of gradational grain-size occur within the sequence and as a whole the grain-size decreases upwards. Following a depositional break, in eastern Britain thin conglomerates were overlain by red marls with evaporates whilst elsewhere a fluviatile sandy facies was deposited. The Sherwood Sandstone Group is overlain by argillaceous rocks of the Mercia Mudstone Group which are in turn overlain by mudstones, limestones and thin sandstones of Jurassic and Cretaceous age. The locations of the principal Mesozoic sedimentary basins are shown in Figure 2.

\subsection{Eastern England Basin}

This basin is the onshore extension of the Southern North Sea Basin. The basal Permian sandstones and breccias are of mixed aeolian and fluvial origin and attain depths of up to $2200 \mathrm{~m}$ near the coast. Only in the east are consistent thicknesses of over $30 \mathrm{~m}$ found. A typical value for intrinsic permeability is $15 \times 10^{-14} \mathrm{~m}^{2}$, but the relatively low thickness results in maximum intrinsic transmissivities of $9.9 \times 10^{-12} \mathrm{~m}^{3}$. The Cleethorpes borehole (see Figure $2 \mathrm{~b}$ ) produced an intrinsic transmissivity of less than $2 \times 10^{-12} \mathrm{~m}^{3}$ and hence the aquifer is not considered to be a viable geothermal resource. An evaporite sequence separates the 
overlying Sherwood Sandstone Group which ranges in thickness from less than $50 \mathrm{~m}$ in the south to more than $500 \mathrm{~m}$ further north. The porosity generally exceeds $20 \%$ and the average intrinsic permeability is considered to be about $25 \times 10^{-14} \mathrm{~m}^{2}$. Within the Sherwood Sandstone of the Cleethorpes borehole an intrinsic transmissivity of greater than $59 \times 10^{-12} \mathrm{~m}^{3}$ was calculated. Figure 3a shows a temperature against depth plot from 451 measurements within the basin. The average geothermal gradient is $31.9{ }^{\circ} \mathrm{C} \mathrm{km}^{-1}$, well above the UK average. Temperatures within the Sherwood Sandstone are expected to be 40 to over $50{ }^{\circ} \mathrm{C}$ and over $60{ }^{\circ} \mathrm{C}$ within the Permian. An equilibrium temperature of $64.5^{\circ} \mathrm{C}$ was measured in the Cleethorpes borehole at a depth of $1850 \mathrm{~m}$ within the Permian sandstone sequence. The basin presents a large, but low temperature resource.

\subsection{Wessex Basin}

Permo-Triassic rocks at depth are restricted to the western parts of the Wessex Basin as a result of syn-depositional faulting during Permo-Triassic times. The basin is split into a number of structural provinces by several significant growth faults. Very coarse-grained Permian deposits, overlain by sandstones, are found locally, but their distribution is uncertain and they are not considered to have geothermal potential. The Sherwood Sandstone Group consists of coarse arenaceous breccias and conglomerates overlain by a series of cyclically deposited sandstones. The degree of cementation varies widely and its effect on porosity and permeability are much more significant than those caused by variations in grain-size or sorting. Porosities up to $26 \%$ have been measured, but due to the cementation variability the majority of the overall transmissivity is often from a few thin layers. The Marchwood and Southampton boreholes on the eastern margin of the basin (see Figure $2 b$ ) produced intrinsic transmissivities of $3.9 \times 10^{-12} \mathrm{~m}^{3}$ and $3.3 \times 10^{-12} \mathrm{~m}^{3}$ at reservoir depths between $1666-1796 \mathrm{~m}$. The main depocentre lies towards the centre of the basin (the Dorset sub-basin) where the thickness is greater than $300 \mathrm{~m}$ at depths of over $2000 \mathrm{~m}$. Within the sub-basin, intrinsic 
transmissivity decreases with depth due to fissure closure and the presence of intergranular carbonate cement, but a value of $15 \times 10^{-12} \mathrm{~m}^{3}$ is expected. The temperature gradient plot from 346 measurements is shown in Figure $3 \mathrm{~b}$ and indicates a geothermal gradient of $34.5^{\circ} \mathrm{C}$ $\mathrm{km}^{-1}$. Over large parts of the basin temperatures are in excess of $50{ }^{\circ} \mathrm{C}$. Equilibrium temperatures of $66^{\circ} \mathrm{C}$ at $1511 \mathrm{~m}$ depth and $76.6^{\circ} \mathrm{C}$ at $1818 \mathrm{~m}$ depth were measured in the Marchwood and Southampton boreholes respectively.

\subsection{Worcester Basin}

The Worcester Basin is a roughly symmetrical graben system, bounded to the west and east by major north-south trending normal faults. Permian sandstones and the Sherwood Sandstone subcrop at depths from a few hundred metres to in excess of $3000 \mathrm{~m}$ with thicknesses in excess of $2250 \mathrm{~m}$ at the basin centre. The Permian is separated from the Sherwood Sandstone by a well-cemented conglomerate sandstone that acts as an aquitard (the Kidderminster Formation). The Bridgnorth Sandstone, of assumed Permian age, is a bright red aeolian deposit with thin marl bands, which reaches a maximum recorded thickness of $938 \mathrm{~m}$ in the Kempsey borehole (see Figure 2b) although thicknesses in excess of $1400 \mathrm{~m}$ are suggested locally from seismic data. It is locally underlain by basal breccias several tens of metres thick. It is unconformably overlain by rocks of the Sherwood Sandstone Group, which attain a maximum thickness in excess of $1000 \mathrm{~m}$ in central and eastern parts of the basin, thicknesses being fault-controlled. The average porosity of the Permian sandstones is $20 \%$ and a typical intrinsic permeability is $15 \times 10^{-14} \mathrm{~m}^{2}$ which is likely to be found over most of the Permian thickness resulting in an intrinsic transmissivity of $113 \times 10^{-12} \mathrm{~m}^{3}$. The Sherwood Sandstone retains its porosity and permeability with depth. Regularly occurring interbeds of argillaceous material reduce the contributory sandstone to less than $50 \%$, but due to their high permeability, intrinsic transmissivities of $79 \times 10^{-12} \mathrm{~m}^{3}$ are expected. There are fewer temperature data than for some of the other basins. Partly due to thinner, low thermal 
conductivity insulating cover, temperatures are expected in the range $40-55{ }^{\circ} \mathrm{C}$. At Kempsey (see Figure 2b) a corrected bottom hole temperature (BHT) of $63{ }^{\circ} \mathrm{C}$ was measured at a depth of $3003 \mathrm{~m}$, although this was in the basement below the Permian.

\subsection{Cheshire Basin}

The Cheshire Basin is roughly elliptical in plan with a long axis trending northeast-southwest. The basin is markedly asymmetrical in cross-section, having, in general terms, the form of a faulted half-graben, deepest in the southeast. The present-day cumulative throw of the faulted southeast margin of the basin approaches, in places, $4000 \mathrm{~m}$. In contrast the western margin of the basin is relatively unfaulted, forming a featheredge characterised by depositional onlap. The internal structure of the basin is complex and, for the most part, heavily faulted. The Permian sandstones are aeolian sands, with dune bedding and 'millet seed' grains expected to have favourable hydrogeological characteristics. An aquiclude (the Manchester Marls Formation) is present in the northern and central parts of the basin. The overlying Sherwood Sandstone is split into five formations comprising conglomerates, pebbly sandstones, finegrained argillaceous and cross-bedded sandstones and massive, well-bedded sandstone. The Permian sandstones vary in thickness from $200 \mathrm{~m}$ at the basin margins to in excess of $1200 \mathrm{~m}$ near the faulted southeast margin at depths in excess of $4000 \mathrm{~m}$. The Sherwood Sandstone is up to $2000 \mathrm{~m}$ thick at depths of $3600 \mathrm{~m}$. Hydrogeological data from depth is sparse, but porosities of $20 \%$ are considered likely and intrinsic transmissivity is believed to exceed $9.9 \mathrm{x}$ $10^{-12} \mathrm{~m}^{3}$. Temperature data are widely scattered on a temperature-depth plot, but suggest a geothermal gradient of $27^{\circ} \mathrm{C} \mathrm{km}^{-1}$. Maximum temperatures at the base Permian are predicted to be almost $100{ }^{\circ} \mathrm{C}$ and at the base Sherwood Sandstone in excess of $80{ }^{\circ} \mathrm{C}$. A corrected BHT of $81{ }^{\circ} \mathrm{C}$ was measured at a depth of $3601 \mathrm{~m}$ in the Prees borehole (see Figure 2b) within the basal Permian breccias. These high temperatures only occur over a few square 
201 kilometers, but temperatures in excess of $50{ }^{\circ} \mathrm{C}$ are found over large areas creating a large 202 geothermal resource.

\subsection{Northern Ireland}

Within Northern Ireland there are three Permo-Triassic basins with geothermal potential. The Rathlin Basin is a transtensional half-graben that formed in response to extension along north northwest-south southeast trending faults. Gravity modelling indicates that the deepest part of the basin occurs against the southeastern faulted margin with depths in excess of $2000 \mathrm{~m}$ and sediments have been proven by drilling to $2650 \mathrm{~m}$ depth. The Lough Neagh Basin is concealed beneath the Palaeogene Antrim Lava Group and within the basin the Sherwood Sandstone is found at depths of $1150 \mathrm{~m}$ (with no underlying Permian sandstone). The asymmetric form of the basin is structurally controlled along its southern flank by northeastsoutheast trending faults. Gravity modelling predicts a basin depth of around $4000 \mathrm{~m}$. The Larne Basin in the east has a predicted oval geometry from gravity modelling and the Larne No. 2 borehole (see Figure 2c) bottomed in Lower Permian volcanics at a depth of $2880 \mathrm{~m}$. The Permian basal layers in the basins are sandstones which are often coarse-grained, but are generally tight such that open sandstones only form a small proportion of the formation. In the Larne No. 2 borehole, Permian sandstone is found below $1823 \mathrm{~m}$ depth and the sandstones include interbedded volcanic tuffs and basalts from $2264 \mathrm{~m}$. These are overlain by an aquiclude (the Upper Permian Marls) and then by the Sherwood Sandstone Group, (between 968-1616 m depth in Larne No. 2) composed mainly of medium-grained sandstones with marl and mudstone intercalations. In the deeper parts of the basins the combined thickness of the Permo-Triassic sandstones may exceed $1000 \mathrm{~m}$. There is very little hydrogeological information from depth. Porosities of $25-30 \%$ have been measured on near surface Permian sandstone and $15-25 \%$ on shallow Sherwood Sandstone. Within the Lough Neagh Basin intrinsic transmissivities of $15 \times 10^{-12} \mathrm{~m}^{3}$ and $2.9 \times 10^{-12} \mathrm{~m}^{3}$ were calculated 
within the upper section of the Sherwood Sandstone and the underlying Permian sandstone respectively. In the Larne No. 2 borehole the intrinsic transmissivity of the Sherwood Sandstone was $7.9 \times 10^{-12} \mathrm{~m}^{3}$ and the Permian sequence only $0.5 \times 10^{-12} \mathrm{~m}^{3}$. Temperatures within the Permo-Triassic succession are expected in the range of $50-70{ }^{\circ} \mathrm{C}$. A drill stem test (DST) temperature of $66^{\circ} \mathrm{C}$ was measured within the Lough Neagh Basin through a depth interval of $1898-1916 \mathrm{~m}$. At the Larne No. 2 borehole the water temperature within the Sherwood Sandstone has an average value of $40{ }^{\circ} \mathrm{C}$ and a corrected BHT of $88{ }^{\circ} \mathrm{C}$ was measured at a depth of $2880 \mathrm{~m}$. Recent drilling of deep boreholes in the southern part of the Rathlin Basin recorded temperatures of $99{ }^{\circ} \mathrm{C}$ at $2650 \mathrm{~m}$.

\section{Geothermal resource assessment}

An assessment of the potential geothermal resource is essential in order to advance exploration to the point of development. However assessments are fraught with problems due to limited sub-surface data and different assumptions. In order to produce standardisation a number of reporting codes have been defined, two of which, the Australian (AGRC, 2010) and Canadian (CGCC, 2010), have become de-facto standards. In accordance with these codes the assessments reported here define the heat in place within the reservoirs as the Inferred Geothermal Resource and that part which might be economically utilised as the Probable Geothermal Reserve.

Resource assessments for the Permo-Triassic sandstones were initially made by Downing and Gray (1986a) and, with the exception of Northern Ireland, were upgraded by Rollin et al. (1995) for the Atlas of Geothermal Resources in Europe (Hurter and Haenel, 2002). More recently revised assessments have been produced for the basins in England by Jackson (2012) and Northern Ireland by Pasquali et al. (2010). These are shown in Table 1. 
249 There are differences between the two assessments. For the Inferred Geothermal Resource, 250 Rollin et al. (1995) and Downing and Gray (1986a) developed models of aquifer structure contours, thicknesses and temperatures and calculated the heat in place over a grid for all resources greater than $40{ }^{\circ} \mathrm{C}$ (the cut-off temperature). The base temperature (i.e. the lower temperature against which the heat in place was calculated) was taken to be the mean annual ground surface temperature, $\sim 10^{\circ} \mathrm{C}$. Jackson (2012) only considered the volume of reservoir for cut-off temperatures above 45, 65, 40 and $65^{\circ} \mathrm{C}$ for the East England, Wessex, Worcester and Cheshire Basins respectively. The heat in place was calculated between a uniform base temperature of $25^{\circ} \mathrm{C}$ and a single average temperature for each reservoir (column 7 in Table 1). For the Larne Basin only, Pasquali (2010) considered a volume constrained by an area of $22.5 \mathrm{~km}^{2}$ which is the radius of influence of a geothermal well doublet over a period of 25 years. The calculations assumed two well doublets with a base temperature of $40{ }^{\circ} \mathrm{C}$. In general, due to the lower base and cut-off temperatures of Rollin et al. (1995) and Downing and Gray (1986a), the Inferred Geothermal Resources are greater than those of Jackson (2012) and Pasquali (2010) with the exception of the Wessex Basin. Probable Geothermal Reserve calculations take into account the hydraulic properties of the aquifer, the method of abstraction, the economic life of the project and the return/reject temperature of the geothermal fluid. Rollin et al. (1995) and Downing and Gray (1986a) used a reject temperature of $25^{\circ} \mathrm{C}$, whilst Jackson (2012) also used $25^{\circ} \mathrm{C}$, but Pasquali (2010) used $40^{\circ} \mathrm{C}$. The Probable Geothermal Reserve will change with time due to technology advances, the costs of other energy sources and the level of incentives available. However, a reasonable estimate of the heat in place that could be exploited as a reserve is around $20 \%$.

The calculations show considerable potential for basins such as the Wessex and Cheshire Basins that have higher temperature resources than the other basins. The Eastern England Basin is the largest, lower temperature resource. Any local exploitation will be dependent on 
local factors such as permeability and it is likely that fracture permeability will be an important factor for the higher groundwater yields.

\section{Matching supply to demand}

Within the UK there is only one direct heat use geothermal scheme in operation located at the city of Southampton on the eastern edge of the Sherwood Sandstone reservoir of the Wessex Basin. The Southampton borehole (see Figure $2 \mathrm{~b}$ ) yields water at $76{ }^{\circ} \mathrm{C}$ from an interval at 1725-1749 m depth, although only a few metres of the reservoir has sufficiently high permeability to contribute to the yield (Downing and Gray, 1986b). The capacity is only 2.8 $\mathrm{MW}_{\text {th }}$ (MegaWatt thermal), but it has been operating since 1988 (Batchelor et al., 2010). In contrast, by the end of 2010, mainland France had $355 \mathrm{MW}_{\text {th }}$ of installed direct-use heat capacity (Ganz, 2012). There are many factors that have resulted in this contrast, including cheap and readily accessible mains gas in the UK from the 1970s, but the location of Paris over a major Mesozoic basin has matched supply with demand.

The UK Department of Energy and Climate Change (DECC) have released a heat demand map (DECC, 2012) for England. The map can be used at different scales to show heat demand at the city or town level, down to individual commercial or public buildings. Figure 4 shows the heat demand at the national scale with a superimposed plot of the Inferred Geothermal Resource for the Sherwood Sandstone Group. The near shore resource within the eastern Irish Sea Basin is also shown on the plot. It can be seen that many of the major heat demand centres, such as London, Birmingham and Manchester do not coincide with the Sherwood Sandstone resource, although a number of smaller cities and towns do. Hence, when considering major heat demand it may be necessary to explore the potential of the Palaeozoic basins. Although rocks of Palaeozoic age are widespread across the UK, Lower Palaeozoics do not form important aquifers at outcrop and it is unlikely that permeability 
would increase with depth. Hence only Upper Palaeozoic sedimentary formations are considered here.

\section{Devonian and Carboniferous basins}

There are large thicknesses of arenaceous and carbonate rocks within the Upper Palaeozoic basins. However, the rocks are hard and compact with low porosities and the intrinsic permeabilities are less than $1 \times 10^{-14} \mathrm{~m}^{2}$ and often less than $0.1 \times 10^{-14} \mathrm{~m}^{2}$. Water flows that do occur are often in fractures and fissures. That there is fracture permeability at depth is demonstrated by the two regions of warm springs at Bath, Bristol and south Wales and in the Peak District around Buxton (Gallois, 2007; Brassington, 2007). The highest temperature recorded of $46{ }^{\circ} \mathrm{C}$ is at Bath where groundwater has risen relatively rapidly through fractured Carboniferous Limestone (Barker et al., 2000).

The distribution of Carboniferous rocks in Britain is shown in Figure 5. Westphalian Coal Measures occur in a number of regions and in places sandstones form significant thicknesses. In the East Midlands, Coal Measures are up to $2800 \mathrm{~m}$ deep where temperatures of $80{ }^{\circ} \mathrm{C}$ can be expected. Sandstone porosities are around $12-15 \%$ and intrinsic permeabilities for the Lower and Middle Coal Measures sandstones range from $0.006 \times 10^{-14}$ to $3.7 \times 10^{-14} \mathrm{~m}^{2}$ and for the Upper Coal Measures from $0.2 \times 10^{-14}$ to $15.8 \times 10^{-14} \mathrm{~m}^{2}$. Cumulative sandstone thicknesses are between 7 and $210 \mathrm{~m}$ resulting in low transmissivities. Thick Coal Measures occur in western England to the southwest of Manchester beneath the Cheshire Basin. The total thickness could be $2500 \mathrm{~m}$ with sandstone forming $25 \%$ of the succession. At these depths (3200-4800 m) temperatures of $80-100{ }^{\circ} \mathrm{C}$ are expected. Little is known about these rocks at depth, but matrix permeabilities are anticipated to be low with any groundwater movement occurring along fractures (Downing and Gray, 1986a). The Upper Coal Measures of south Wales are predominantly thick, massive, feldspathic and micaceous sandstones with 
sandstone thicknesses from $900 \mathrm{~m}$ in the west to $240 \mathrm{~m}$ in the east. Depths are generally shallow with a maximum of around $1500 \mathrm{~m}$ in the southwest of the coalfield. The south Wales Lower and Middle Coal Measures are predominantly argillaceous with a number of sandstones of wide lateral extent. They attain depths of more than $2000 \mathrm{~m}$ in the south with some sandstones up to $50 \mathrm{~m}$ thick, but their total thickness is not significant. Temperatures of up to $60{ }^{\circ} \mathrm{C}$ have been inferred (Downing and Gray, 1986a). The sandstones are hard and dense and secondary cementation has led to low matrix porositiy and permeability. Sandstone intrinsic transmissivities are less than $1 \times 10^{-12} \mathrm{~m}^{3}$ to $20 \times 10^{-12} \mathrm{~m}^{3}$ where the permeability is from fissure flow. The fissures are assumed to close with depth as the deeper mines in the west are generally dry. Most of the remaining Coal Measures within the UK occur at shallower depths where temperatures are unlikely to exceed $40^{\circ} \mathrm{C}$.

The Namurian rocks beneath the Coal Measures typically comprise Millstone Grit in central areas of England, but comparable facies are found in south Wales, northern England, and the Midland Valley of Scotland. Millstone Grit consists of a series of cyclical sequences with a basal argillaceous succession overlain by fine to coarse grained sandstones. Its equivalent northwards has an increased proportion of limestone and coal, although sandstone still dominates. Individual channel-sandstones may be up to $60 \mathrm{~m}$ thick and the cumulative total may exceed $150 \mathrm{~m}$, but is commonly less than $100 \mathrm{~m}$. Intergranular porosities and permeabilities are low, but there may be some local fracturing to depths of over $1000 \mathrm{~m}$. Namurian rocks underlie the Permo-Triass and Coal Measures of the Eastern England Basin. In places sandstone comprises $50 \%$ of the succession which may be up to $1000 \mathrm{~m}$ thick and buried to depths of $1200 \mathrm{~m}$ where temperatures of $60{ }^{\circ} \mathrm{C}$ can be expected. At outcrop, the Millstone Grit is exploited as a minor aquifer, but groundwater flow decreases rapidly with depth due to fracture closure. These eastern England Namurian sandstones, at depth, form oil and gas reservoirs and within the oilfield porosities of up to $20 \%$ and intrinsic permeabilities 
347 up to $3 \times 10^{-14} \mathrm{~m}^{2}$ have been measured (Downing and Gray, 1986a). However transmissivities

are not thought to be high enough to form a geothermal reservoir. Thick successions of Millstone Grit (more than $1800 \mathrm{~m}$ ) occur to the north and south of Manchester at depths of up to $6000 \mathrm{~m}$ and equivalent Namurian rocks in the Midland Valley of Scotland occur mainly at depths of less than $500 \mathrm{~m}$. In south Wales the Millstone Grit comprises sandstones and shales up to $600 \mathrm{~m}$ thick and at depths of over $1500 \mathrm{~m}$, but porosities and permeabilities are expected to be low.

Carboniferous limestone in the UK forms several upland features and comprises Dinantian shallow water shelf carbonate. Intergranular porosities and permeabilities are uniformly low, although dolomitisation may increase porosity to a maximum of about $10-12 \%$. Groundwater flow in the near surface is via fissures and fractures enlarged by solution and at depth there be may some Palaeokarst from exposure of the limestone in the Dinantian, Namurian, Permian and Mesozoic. That fissure flow at depth is possible is attested to by the warm springs described above. In the East Midlands, in the vicinity of the Eastern England Basin, the Carboniferous Limestone is up to $2200 \mathrm{~m}$ in depth and a thickness of $1800 \mathrm{~m}$ has been proved (Downing and Gray, 1986a). Any groundwater movement will be by fissure flow. Oil exploration boreholes only found high flow rates at a few sites, indicating low intrinsic permeabilities and intrinsic transmissivities of $0.3 \times 10^{-14} \mathrm{~m}^{2}$ and $0.1 \times 10^{-12} \mathrm{~m}^{3}$ respectively. A small thermal high (the Eakring anomaly) measured in boreholes has also been attributed to deep groundwater movement (Bullard and Niblett, 1951). Wilson and Luheshi (1987) modelled this anomaly as arising from the ascent of water up a steep faulted anticline in the Lower Carboniferous Limestone. In the west, around Manchester, Carboniferous Limestone is found at depth beneath the Millstone Grit where temperatures may exceed $140{ }^{\circ} \mathrm{C}$. It has been proposed to develop this resource for a direct use heating scheme for Manchester (GT Energy 2012). In southern England, Carboniferous Limestone occurs at depth in an easterly 
trending deformed belt. In south Wales, beneath the southern coalfield, the base of the limestone is over $3000 \mathrm{~m}$ in depth and over $1500 \mathrm{~m}$ under extensive areas of the south western coalfield. Outcrops of Carboniferous Limestone are also found in the Bath-BristolMendips area. The thermal springs across this region indicate fissure flow at depth with flow lengths of possibly several tens of kilometres (Downing and Gray, 1986a).

In northern England and Scotland the lateral equivalents of the Carboniferous Limestone are rocks in which shales and sandstones dominate and limestone is of less importance. The main sandstone sequence of geothermal interest is the Fell Sandstone of the Middle Border Group that is found at depth in the Northumberland Trough to the north of Newcastle upon Tyne. The sandstone is fine to medium grained and can make up to $60 \%$ of the Fell Sandstone succession. At outcrop the hydrogeological properties are variable, but good aquifers occur with porosities up to $33 \%$ with a mean around $14 \%$. At depth, in the Stonehaugh borehole, the Fell Sandstone was penetrated between depths of 399-600 m. The mean porosity was $7.2 \%$, the mean horizontal intrinsic permeability was $2 \times 10^{-14} \mathrm{~m}^{2}$ and the mean vertical intrinsic permeability was $7.2 \times 10^{-14} \mathrm{~m}^{2}$. An intrinsic transmissivity of $1.2 \times 10^{-12} \mathrm{~m}^{3}$ was calculated from the horizontal intrinsic permeability. Permeabilities are likely to be enhanced at depth by fissure flow. It has been suggested that major fault zones, such as the southerly bounding fault (the Ninety Fathom-Stublick fault zone) of the Northumberland Trough may enable groundwater convection (Younger et al., 2012). In this case the North Pennine granitic batholith (formerly known as the Weardale granite), which is a buried high heat producing granite to the west southwest of Newcastle upon Tyne (Kimbell et al., 2010), could be the source of warmer water that then migrates eastwards. A borehole in the centre of Newcastle upon Tyne (Science Central) recently intersected $377 \mathrm{~m}$ of Fell Sandstone below a depth of $1419 \mathrm{~m}$ and recorded a temperature of $73{ }^{\circ} \mathrm{C}$ at a depth of $1767 \mathrm{~m}$, indicating a geothermal 
396 gradient of $36^{\circ} \mathrm{C} \mathrm{km}^{-1}$. Figure 6 illustrates the position of the borehole on the southern margin of the Northumberland Trough.

The distribution of Devonian rocks in Britain is shown in Figure 7. Of geothermal interest is the Old Red Sandstone (ORS) that comprises sandstones, shales and conglomerates. In southern England buried ORS occurs with thicknesses in excess of $2000 \mathrm{~m}$. In south Wales several hundred metres of the upper part of the Lower ORS and Upper ORS have water potential, but the well cemented and indurated rocks have low porosities and permeabilities. ORS and associated volcanic rocks occur extensively beneath Carboniferous cover in the Midland Valley of Scotland. The sequence consists predominantly of sandstone with subordinate mudstone and is usually over $500 \mathrm{~m}$ thick (1000 $\mathrm{m}$ in the west) and is found at depths of 500-4000 m. The Upper ORS is an important fresh water aquifer with the Knox Pulpit Formation in particular measuring porosity greater than $20 \%$ and intrinsic permeability greater than $59 \times 10^{-14} \mathrm{~m}^{2}$. This formation is not cemented, but despite the high permeability, $70 \%$ of the transmissivity is derived from fracture flow. If the hydrogeological properties extend to depth then the eastern Midland Valley offers the best potential for geothermal reservoirs within the Upper ORS. Lower ORS also attains great thicknesses within the Midland Valley but low permeability results in predicted intrinsic transmissivities of only 2.5 $\mathrm{x} 10^{-12} \mathrm{~m}^{3}$. In northern Scotland the Orcadian Basin is known to have ORS thicknesses of around $4000 \mathrm{~m}$. Extremely high vitrinite reflectance values and spore colours developed over an extensive $\left(\sim 300 \mathrm{~km}^{2}\right)$ area of ORS rocks within the basin are inferred to result from contact metamorphism by a large, concealed Late Devonian pluton (the 'Caithness Granite') (Gillespie, 2009). Although no other evidence has been presented for a buried granite it could possibly lead to elevated heat flow and geothermal gradients.

\section{Conclusions}


Within the onshore Mesozoic basins the Permo-Triassic sandstones are a considerable geothermal resource. The Inferred Geothermal Resource has been calculated by two slightly different methodologies that indicate a resource between $201 \times 10^{18}$ and $328 \times 10^{18} \mathrm{~J}$. Estimates of the Probable Geothermal Reserve are based on a number of assumptions, but key to any exploitation is local permeability and transmissivity. High temperatures are found in the basin depocentres that are generally fault bounded. These faults may have an intrinsic fracture permeability that could considerably enhance the local geothermal reserve. The heat demand map demonstrates that a number of towns are ideally situated to take advantage of the geothermal heat potential with the development of district heating schemes. Agricultural applications such as greenhouse heating could also use this considerable resource. The potential of Palaeozoic aquifers is far less clear. Although large thicknesses of arenaceous deposits at great depth are known there is little data on hydrogeological properties at depth. Important productive aquifers occur at shallow depth, but they tend to be locally developed and often a significant proportion of the yield is from fissure flow. It is anticipated that much of the fracture permeability will diminish rapidly with depth. One possible exception is the development of palaeokarst in the Carboniferous Limestone. The warm springs in the BathBristol-south Wales and Peak District areas show that fracture flow to depth does occur and the thermal anomaly at Eakring in the East Midlands has been modelled as fluid movement from depth within the buried Carboniferous Limestone. Reservoir stimulation has been used for many years in the hydrocarbons industry utilizing both artificial fracturing and chemical methodologies. The transfer of these technologies to geothermal has been mainly for power generation where chemical methods have been used to clean wells and improve near bore permeability, e.g. Barrios et al., 2007; Nami et al., 2008 and hydrofracing of EGS reservoirs, e.g. Evans et al., 2005. The limited use of these stimulation techniques in direct use applications is most likely due to economic considerations. However, if such techniques 
could be successfully applied to the Palaeozoic aquifers then some of the large heat demand centers would have access to a geothermal resource.

Jackson (2012) also carried out a financial analysis based on current engineering practices and the level of financial support available from the UK government in 2012 for renewable heat. The current level of support was judged to be too low to adequately stimulate heat only projects and therefore by 2030 the projected installed capacity is estimated to be only around $80 \mathrm{MWth}$. Advances in drilling and engineering techniques, increased fossil fuel prices and increasing incentives for renewable energy may change this outlook and lead to the full exploitation of the UK's HSA resources.

\section{Acknowledgements}

This paper is published by permission of the Executive Director of the British Geological Survey (NERC).

\section{References}

AGRC 2010. The Geothermal Reporting Code. Australian Code for Reporting of Exploration Results, Geothermal Resources and Geothermal Reserves Second Edition (2010).

Barker, J. A., Downing, R. A., Gray, D. A., Findlay, J., Kellaway, G. A., Parker, R. H. and Rollin, K. E. 2000. Hydrogeothermal studies in the United Kingdom. Quarterly Journal of Engineering Geology and Hydrogeology, 33, 41-58.

Barrios, L.A., J. Quijano, E. Guerra, H. Mayorga, A. Rodríguez, and R. Romero. 2007. Injection Improvements in Low Permeability and Negative Skin Wells, Using Mechanical Cleanout and Chemical Stimulation, Berlin Geothermal Field, El Salvador. Geothermal Resources Council Transactions, 31, 141-146. 
Batchelor, T., Curtis, R. and Ledingham, P. 2010. Country update for the United Kingdom. Proceedings World Geothermal Congress 2010 Bali, Indonesia, 25-29 April 2010.

Bennett, J. R. P. 1980. The sedimentary Basins in Northern Ireland. Investigation of the geothermal potential of the UK, Institute of Geological Sciences, London.

Bott, M. H. P., Swinburn, P. M. \& Long, R. E. 1984. Deep structure and origin of the Northumberland and Stainmore troughs. Proceedings of the Yorkshire Geological Society, 44, 479-495.

Brassington, F. C. 2007. A proposed conceptual model for the genesis of the Derbyshire thermal springs. Quarterly Journal of Engineering Geology and Hydrogeology, 40, 3546.

Bullard, E. C. 1939. Heat flow in South Africa. Proceedings of the Royal Society of London, $A, 173,428-50$.

Bullard, E. C. and Niblett, E. R. 1951. Terrestrial heat flow in England. Monthly Notices of the Royal Astronomical Society. Geophysical Supplement, 6, 222-238.

CGCC, 2010. The Canadian Geothermal Code for Public Reporting. Reporting of exploration results, geothermal resources and geothermal reserves, 2010 edition.

Chadwick, R A and Pharaoh, T C. 1998. The seismic reflection Moho beneath the United Kingdom and adjacent areas. Tectonophysics, Vol. 299, 255-279.

DECC 2009. The UK Renewable Energy Strategy. Department of Energy and Climate Change, London.

DECC 2011. UK Renewable Energy Roadmap. Department of Energy and Climate Change, London. 
DECC 2012. The National Heat Map. http://tools.decc.gov.uk/nationalheatmap/ (cited August 2013).

Downing, R. A., Burgess, W. G., Smith, I. F., Allen, D. J., Price, M. and Edmunds, W. M. 1982. Geothermal aspects of the Larne No. 2 Borehole. Investigation of the geothermal potential of the UK, Institute of Geological Sciences, London.

Downing, R. A. and Gray, D. A. (eds.) 1986a. Geothermal Energy - The potential in the United Kingdom. HMSO, London.

Downing, R. A. and Gray, D. A. 1986b. Geothermal resources of the United Kingdom. Journal of the Geological Society, London, 143, 499-507.

Evans, K.F, Moriya, H., Niitsuma, H., Jones, R. H., Phillips, W. S. and Genter, A. 2005. Microseismicity and permeability enhancement of hydrogeologic structures during massive fluid injections into granite at $3 \mathrm{~km}$ depth at the Soultz HDR site. Geophysical Journal International, 160, 389-412

Fraser, A J, Nash, D F, Steele, R P and Ebdon, C C. 1990. A regional assessment of the intra-Carboniferous play of northern England. 417-440 in Classic Petroleum Provinces. Brooks, J (editor), Geological Society of London, Special Publication, No. 50.

Gallois R. 2007. The formation of the hot springs at Bath Spa, UK. Geological Magazine, $144,741-747$.

Ganz, B. 2012. Trends in Geothermal Applications: Survey report on geothermal utilisation and development in IEA-GIA member countries in 2010. Publication of the IEA Geothermal Implementing Agreement, July 2012. http://iea-gia.org/2010-trend-reportannex-X-available/ (cited February 2013)

Gillespie,M. R. 2009. The potential for developing enhanced geothermal systems in Scotland. Internal Report, British Geological Survey, Keyworth. 
513

514

515

516

GT Energy 2012. Project update; Geothermal Energy in Manchester. The $2^{\text {nd }}$ UK Deep Geothermal Symposium. EGS Energy Ltd., Burlington House, London. October 15 2012.

S. Hurter and R. Haenel (Eds.), Atlas of Geothermal Resources in Europe, Office for Official Publications of the European Communities, Luxemburg, 2002.

Jackson. T. 2012. Geothermal potential in Great Britain and Northern Ireland. A report by Sinclair Knight Merz.

Kimbell, G. S., Young, B., Millward, D. and Crowley, Q. G. 2010. The North Pennine batholith (Weardale Granite) of northern England: new data on its age and form. Proceedings of the Yorkshire Geological Society 58, 107-128.

Lee, M. K., Brown, G. C., Webb, P. C., Wheildon, J. and Rollin, K. E. 1987. Heat flow, heat production and thermo-tectonic setting in mainland UK. Journal of the Geological Society, London, 144, 35-42.

Leeder, M R 1982. Upper Palaeozoic basins of the British Isles Caledonide inheritance versus Hercynian plate margin processes. Journal of the Geological Society, London, 139, 479-491.

Mitchell, W. I. (ed.) 2004. The geology of Northern Ireland-Our natural foundation, $\left(2^{\text {nd }}\right.$ edition). Geological Survey of Northern Ireland, Belfast.

Nami, P. Schellschmidt, R. Schindler and M. Tischner, T. 2008. Chemical stimulation operations for reservoir development of the deep crystalline HDR/EGS system at Soultz-Sous-Forets France. PROCEEDINGS, Thirty-Second Workshop on Geothermal Reservoir Engineering, Stanford University, Stanford, California, January 28-30, 2008, SGP-TR-185. 
536 Pasquali, R., O’Neill, N., Reay, D. and Waugh, T. 2010. The geothermal potential of Northern Ireland. Proceedings World Geothermal Congress 2010. Bali, Indonesia, 2529 April 2010.

Reay, D. and Kelly, J. 2010. Deep Geothermal Energy Resource Potential of Northern Ireland European Geologist, 29, 14-18. European Federation of Geologists.

Rollin, K. E. 1995. A simple heat-flow quality function and appraisal of heat-flow measurements and heat-flow estimates from the UK Geothermal Catalogue. Tectonophysics, 244, 185-196.

Singhal, B. B. S. and Gupta, R. P. 2010. Applied Hydrogeology of Fractured Rocks. Springer Dordrecht, Heidelberg, London, New York.

Rollin, K. E., Kirby, G. A., Rowley, W. J. and Buckley, D. K. 1995. Atlas of Geothermal Resources in Europe: UK Revision. Technical Report WK/95/07, British Geological Survey, Keyworth.

Wilson, N. P. and Luheshi, M. N. 1987. Thermal aspects of the East Midlands aquifer system. In: Goff, J. C. and Williams, B. P. J. (eds.) Fluid flow in sedimentary basins and aquifers. Geological Society Special Publication, 34, 157-169.

Younger, P. L., Gluyas, J. G. and Stephens, W. E. 2012. Development of deep geothermal energy resources in the UK. Proceedings of the Institution of Civil Engineers; Energy, 165, 19-32. 
Table 1. Geothermal resource estimates for the principal Mesozoic sedimentary basins in the UK.

\begin{tabular}{|c|c|c|c|c|c|c|c|c|}
\hline \multirow[t]{2}{*}{ Basin } & \multirow[t]{2}{*}{ Aquifer } & \multicolumn{3}{|c|}{$\begin{array}{c}\text { Rollin et al. (1995), } \\
\text { Downing and Gray (1986a) }\end{array}$} & \multicolumn{4}{|c|}{ Jackson (2012), Pasquali (2010) } \\
\hline & & $\begin{array}{l}\text { Area } \\
\left(\mathrm{km}^{2}\right)\end{array}$ & $\begin{array}{c}\text { IGR } \\
\left({\mathrm{x} 10^{18}}^{\mathrm{J}}\right)\end{array}$ & $\begin{array}{l}\text { PGR }\left(x 10^{18}\right. \\
\text { J) }\end{array}$ & $\begin{array}{l}\text { Area } \\
\left(\mathrm{km}^{2}\right)\end{array}$ & $\begin{array}{c}\text { Reservoir } \\
\text { Temp }\left({ }^{\circ} \mathbf{C}\right)\end{array}$ & $\begin{array}{c}\text { IGR } \\
\left({\left.\mathrm{x} 10^{18} \mathrm{~J}\right)}^{\mathrm{I}}\right.\end{array}$ & $\begin{array}{l}\text { PGR } \\
\text { (MWth) }\end{array}$ \\
\hline Eastern England & SSG Triassic & 4827 & 122.2 & 24.6 & $\mathbf{8 5 0}$ & 50 & 19.4 & 12000 \\
\hline Wessex & SSG Triassic & 4188 & 27.2 & 6.5 & 3000 & 80 & 124 & 59000 \\
\hline \multirow[t]{2}{*}{ Worcester } & SSG Triassic & 500 & 8.2 & 1.5 & \multirow{2}{*}{$\mathbf{2 0 0}^{\dagger}$} & \multirow{2}{*}{$45^{\dagger}$} & \multirow{2}{*}{$10.6^{\dagger}$} & \multirow{2}{*}{$6700^{\dagger}$} \\
\hline & BS Permian & 1173 & 60.3 & 11.8 & & & & \\
\hline \multirow[t]{2}{*}{ Cheshire } & SSG Triassic & 677 & 36.2 & 7.6 & \multirow{2}{*}{$680^{\dagger}$} & \multirow{2}{*}{$75^{+}$} & \multirow{2}{*}{$44.1^{\dagger}$} & \multirow{2}{*}{$28000^{\dagger}$} \\
\hline & CS Permian & 1266 & 38.5 & 9.1 & & & & \\
\hline Northern Ireland & SSG Triassic & $1618^{+}$ & $35^{+}$ & $8.0^{+}$ & $22.5^{*}$ & 85* & 3.1* & $1600 *$ \\
\hline
\end{tabular}

Note

IGR is the Inferred Geothermal resource and PGR is the Probable Geothermal Reserve Area refers to the area of the basin used in the assessment

SSG Sherwood Sandstone Group; BS Bridgnorth Sandstone; CS Collyhurst Sandstone

+ Northern Ireland assessment from Downing and Gray (1986a), all other basins from Rollin et al. (1995)

$\uparrow$ Assessment is for the combined Permo-Triassic sandstones

* Northern Ireland assessment is from Pasquali (2010) and only considers the combined Permo-Triassic sandstones from the Larne Basin, all other basins are from Jackson (2012)

\section{Figures}

Figure 1. Heat flow map of the UK.

Figure 2. Principal Mesozoic basins within the UK a) general location map of the Eastern England, Wessex, Worcester, Cheshire and Northern Ireland Basins, b) basins in England (and partly Wales) shown with depth to base of the Permo-Triassic sandstones, c) sketch of basin locations in Northern Ireland (after Reay and Kelly, 2010). Red squares are deep 
boreholes referred to in the text: $C L$, Cleethorpes; $K P$, Kempsey; $L A$, Larne No. $2 ; M W$, Marchwood; PR, Prees; and Southampton.

Figure 3. Temperature versus depth plots for a) the Eastern England Basin - the regression line gives an average geothermal gradient of $31.9^{\circ} \mathrm{C} \mathrm{km}^{-1}$, and b) the Wessex Basin where the average geothermal gradient is $34.5^{\circ} \mathrm{C} \mathrm{km}^{-1}$.

Figure 4. Heat demand map for England displayed at national scale with the heat in place (Inferred Geothermal Resource) for the Sherwood Sandstone Group as an overlay. The heat demand map is displayed on a rainbow scale as a total heat density from 86 to $0.00017 \mathrm{kWh}$ $\mathrm{m}^{-2}$. The heat in place is displayed as an energy density in GJ $\mathrm{m}^{-2}$ with $30 \%$ transparency to allow the heat demand map to be seen in areas with heat in place.

Figure 5. Distribution of Carboniferous rocks in Britain displayed as a regional map of relative depth to the base of the Carboniferous. Darker areas show the greatest depths.

Figure 6. Location of the Science Central borehole to the south of the southerly bounding fault (the Ninety Fathom-Stublick fault zone) of the Northumberland Trough. Areas in red show where there is granite within the crust.

Figure 7. Distribution of Devonian rocks in Britain displayed as a regional map of relative depth to the base of the Devonian. Darker areas show the greatest depths. 


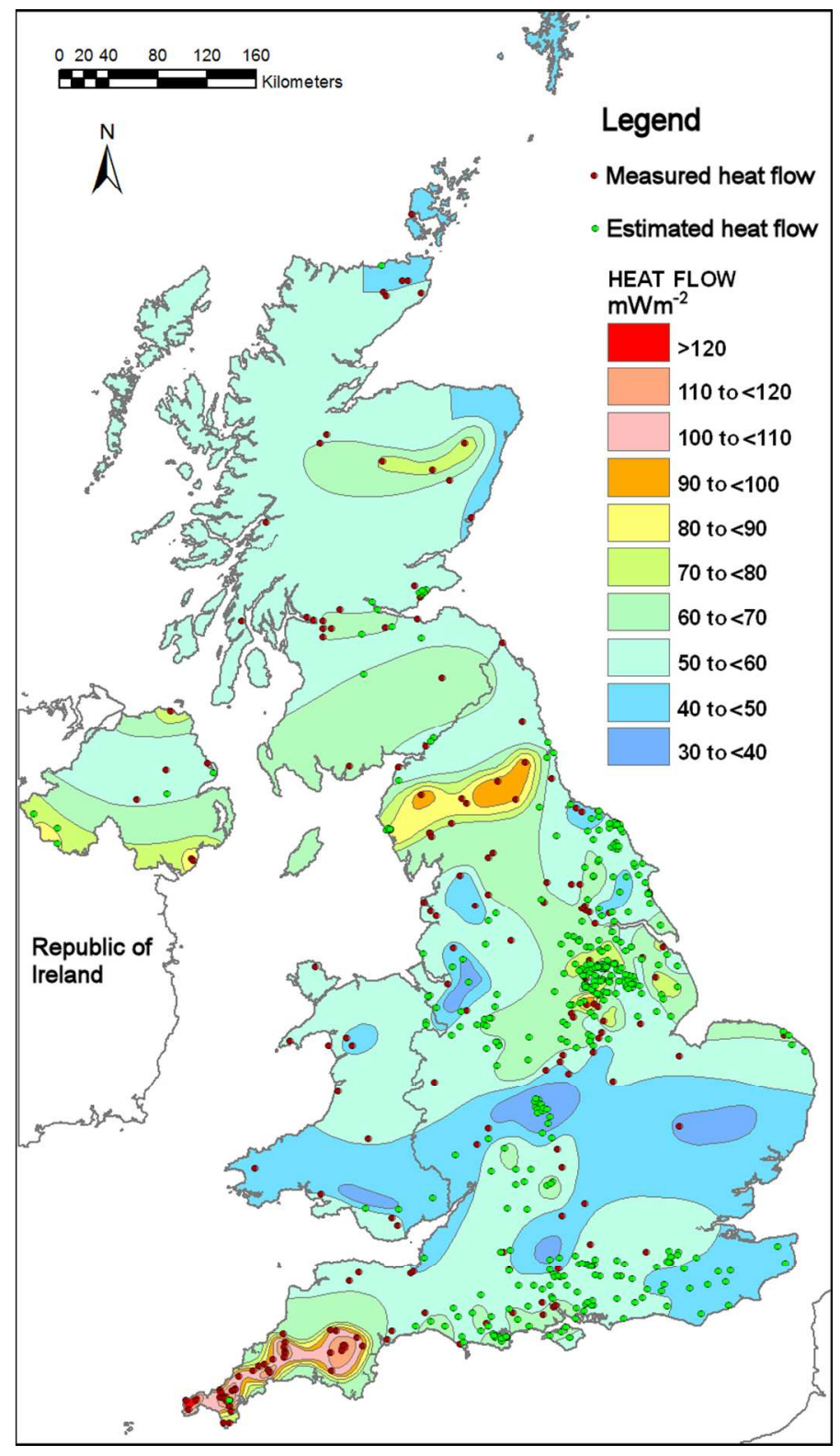

Figure 1. Heat flow map of the UK. $146 \times 257 \mathrm{~mm}(150 \times 150 \mathrm{DPI})$ 


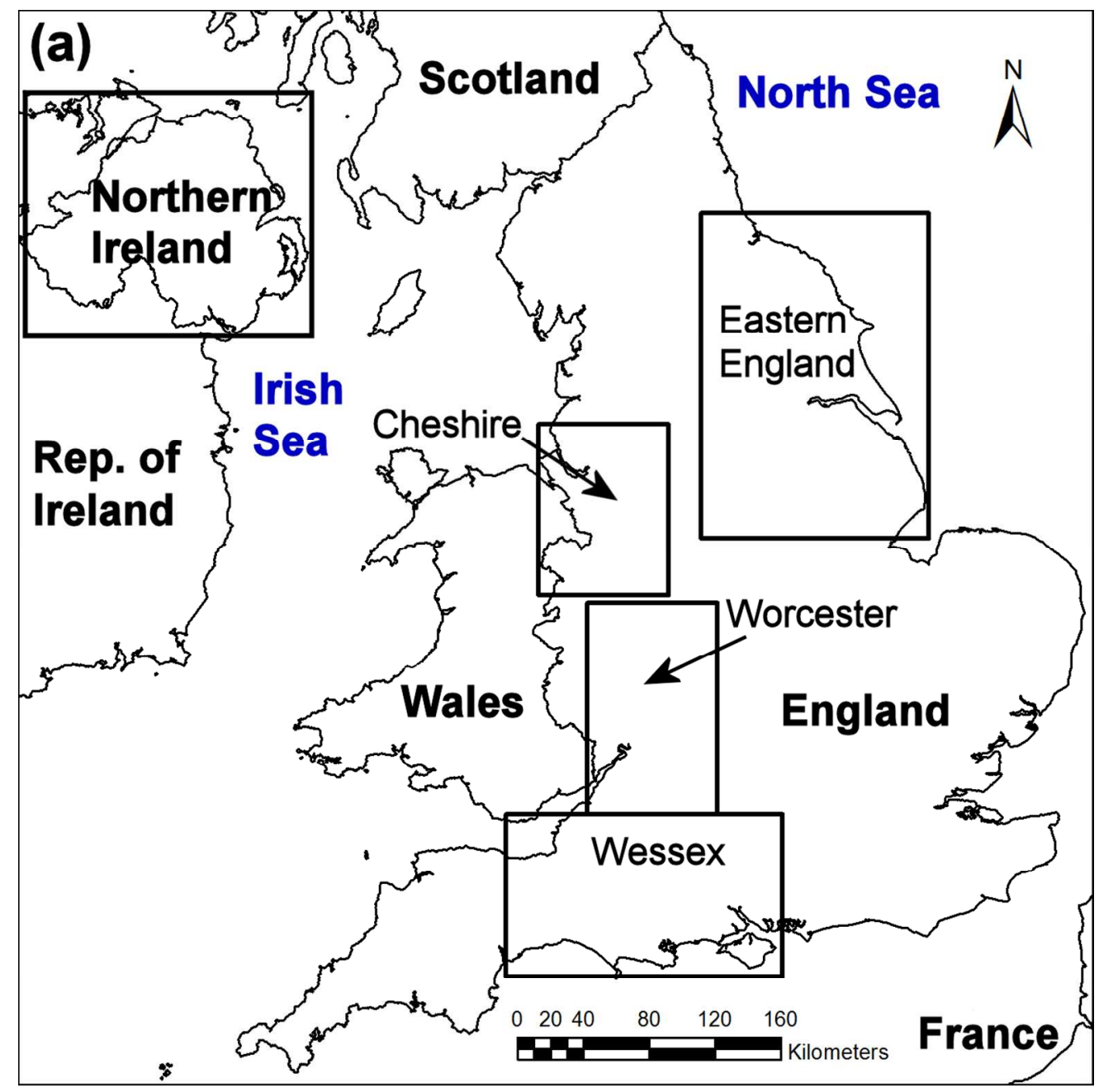

Figure 2. Principal Mesozoic basins within the UK a) general location map of the Eastern England, Wessex, Worcester, Cheshire and Northern Ireland Basins, $176 \times 176 \mathrm{~mm}(200 \times 200 \mathrm{DPI})$ 


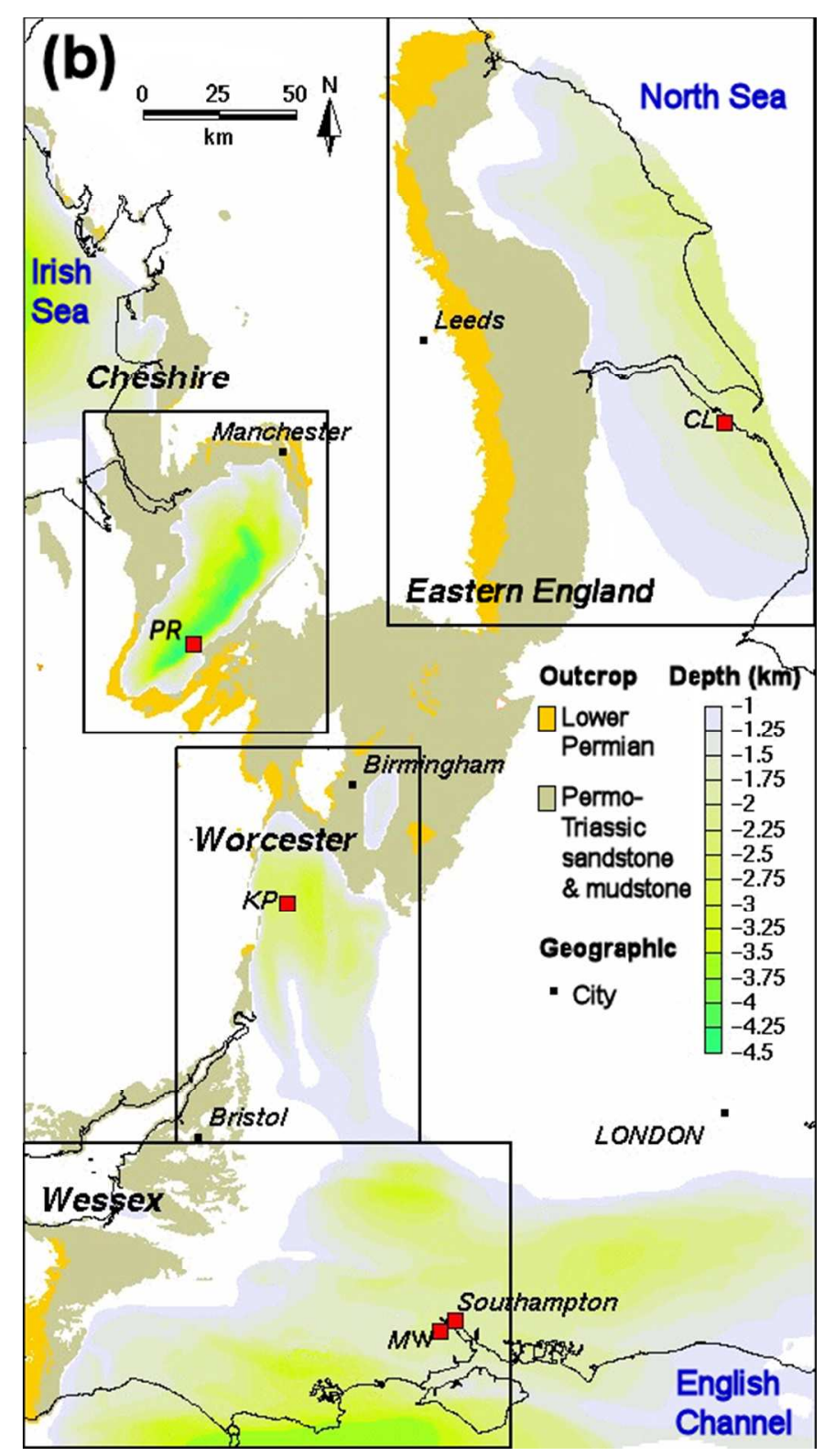

, b) basins in England (and partly Wales) shown with depth to base of the Permo-Triassic sandstones, 


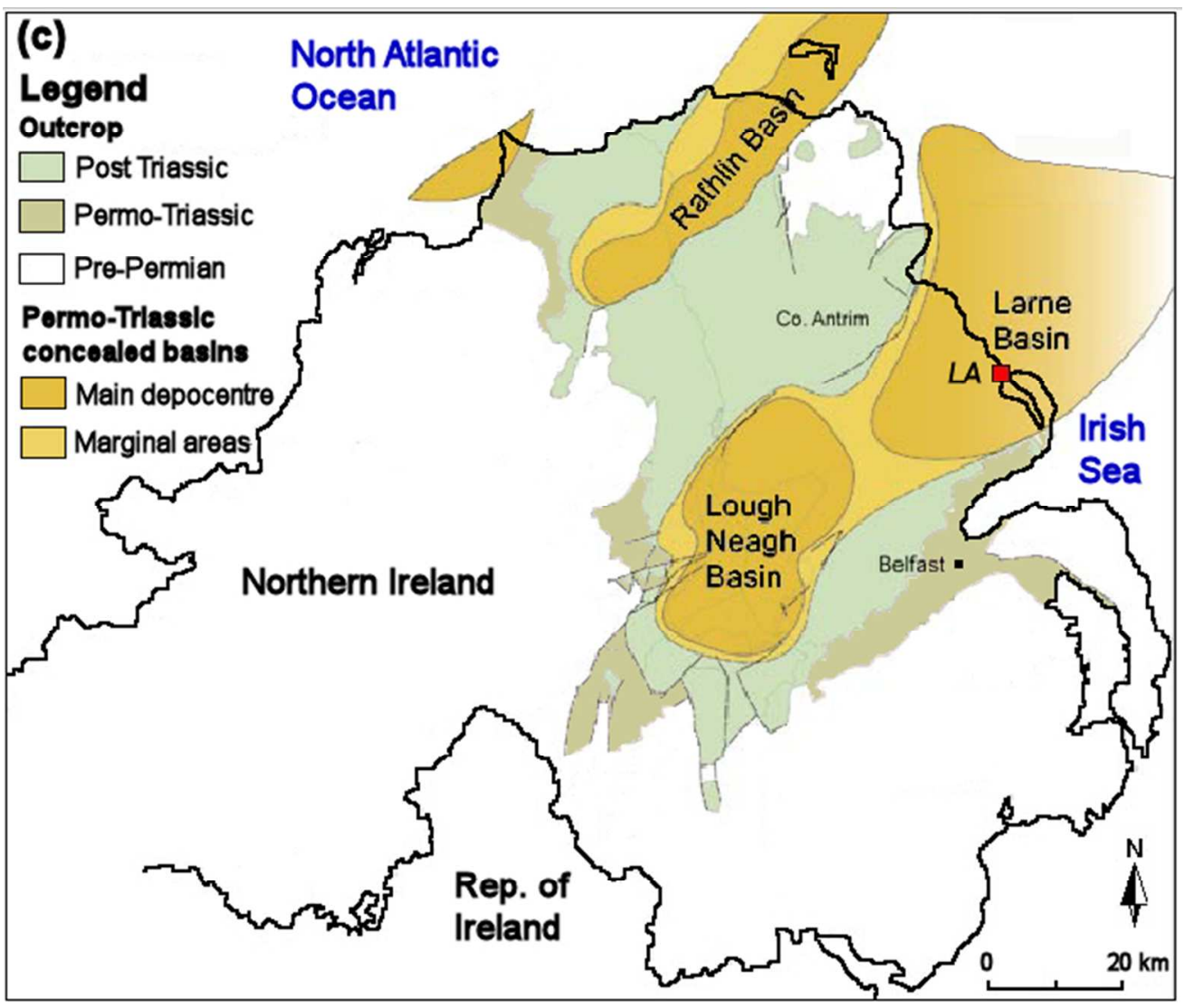

c) sketch of basin locations in Northern Ireland (after Reay and Kelly, 2010). Red squares are deep boreholes referred to in the text: CL, Cleethorpes; KP, Kempsey; LA, Larne No. 2; MW, Marchwood; PR, Prees; and Southampton. $184 \times 156 \mathrm{~mm}(96 \times 96 \mathrm{DPI})$ 


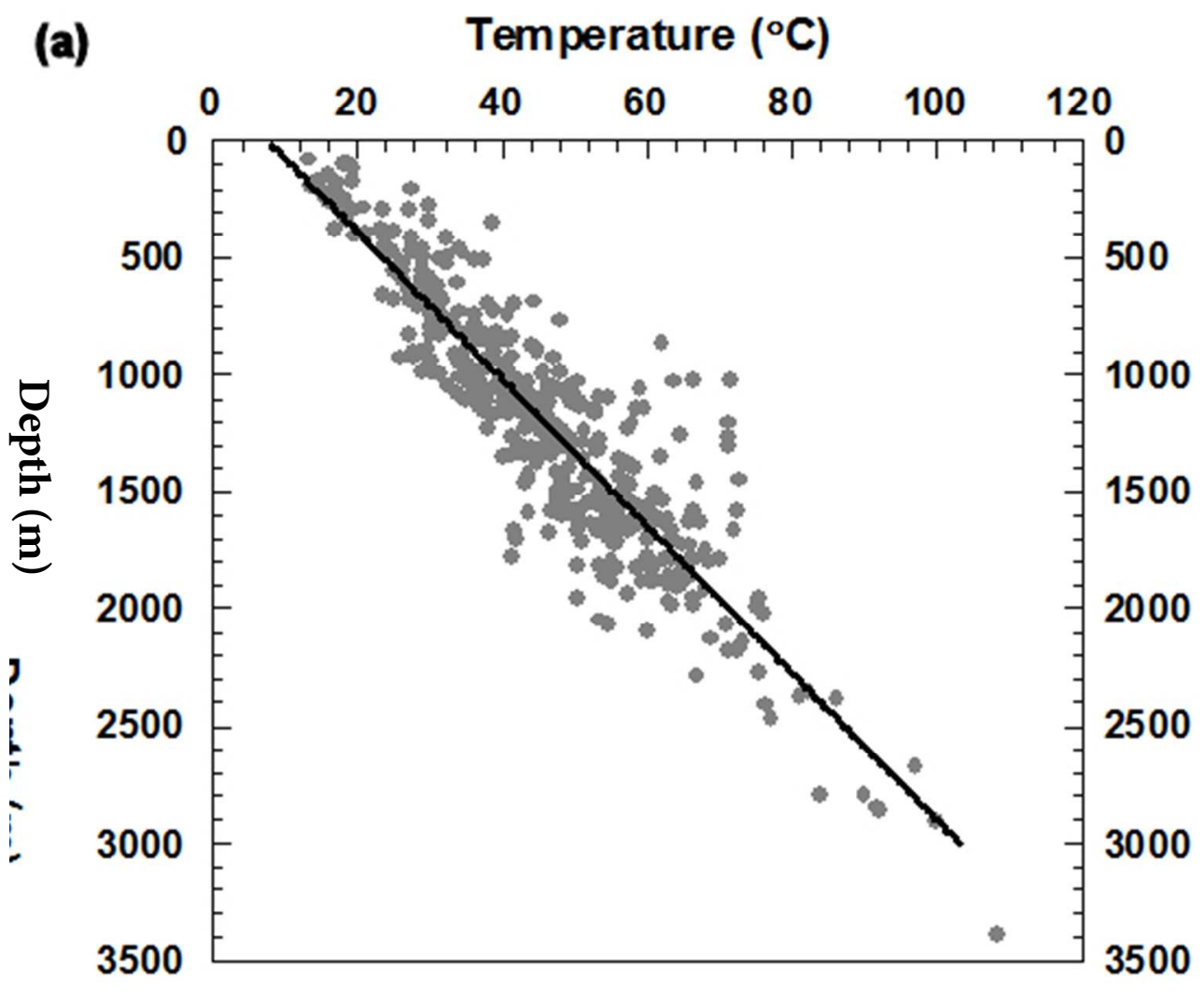

Figure 3. Temperature versus depth plots for a) the Eastern England Basin - the regression line gives an average geothermal gradient of $31.9^{\circ} \mathrm{C} \mathrm{km}-1$, $196 \times 166 \mathrm{~mm}$ (72 x 72 DPI) 


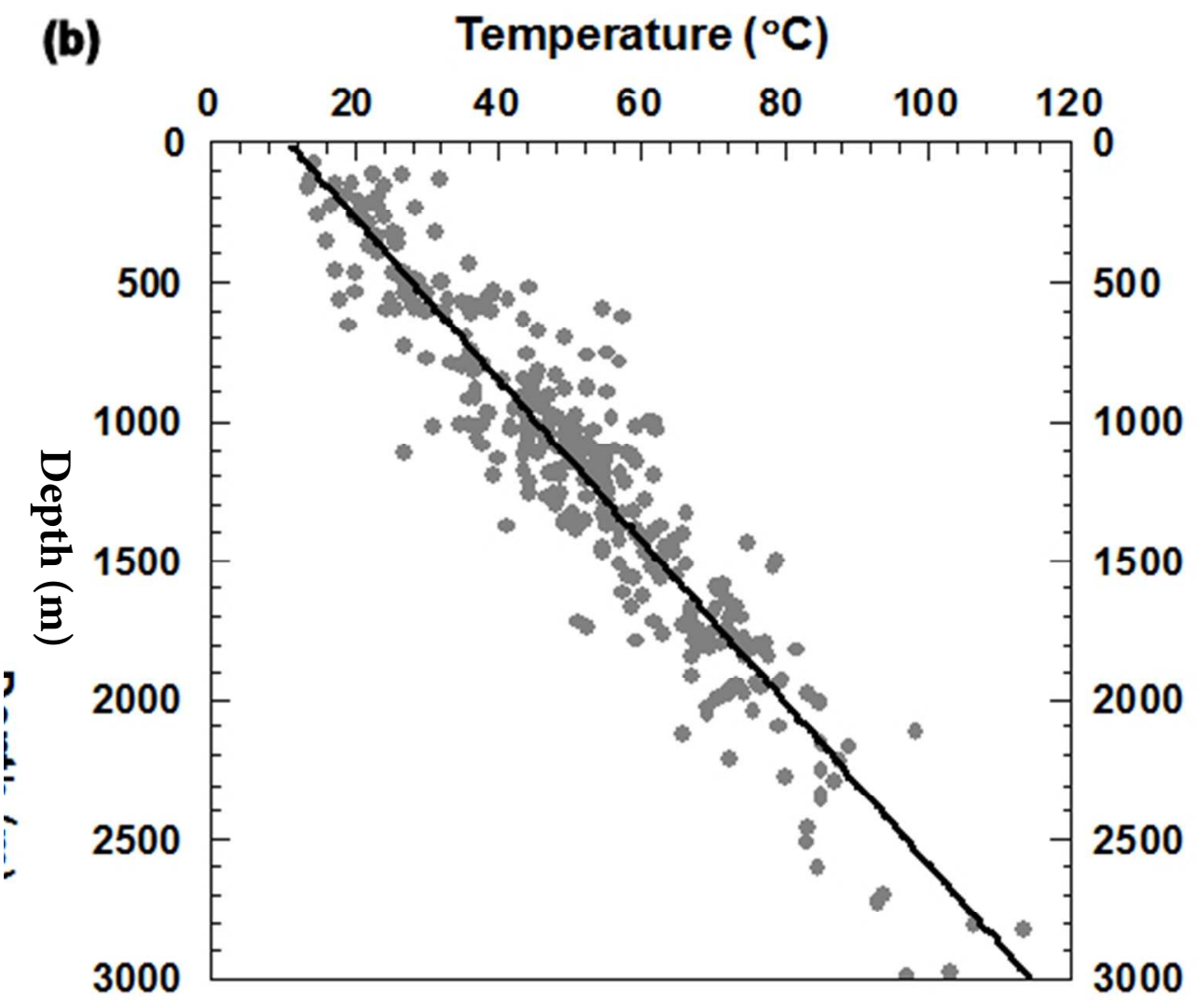

and b) the Wessex Basin where the average geothermal gradient is $34.5^{\circ} \mathrm{C} \mathrm{km}-1$. $192 \times 166 \mathrm{~mm}(72 \times 72 \mathrm{DPI})$ 


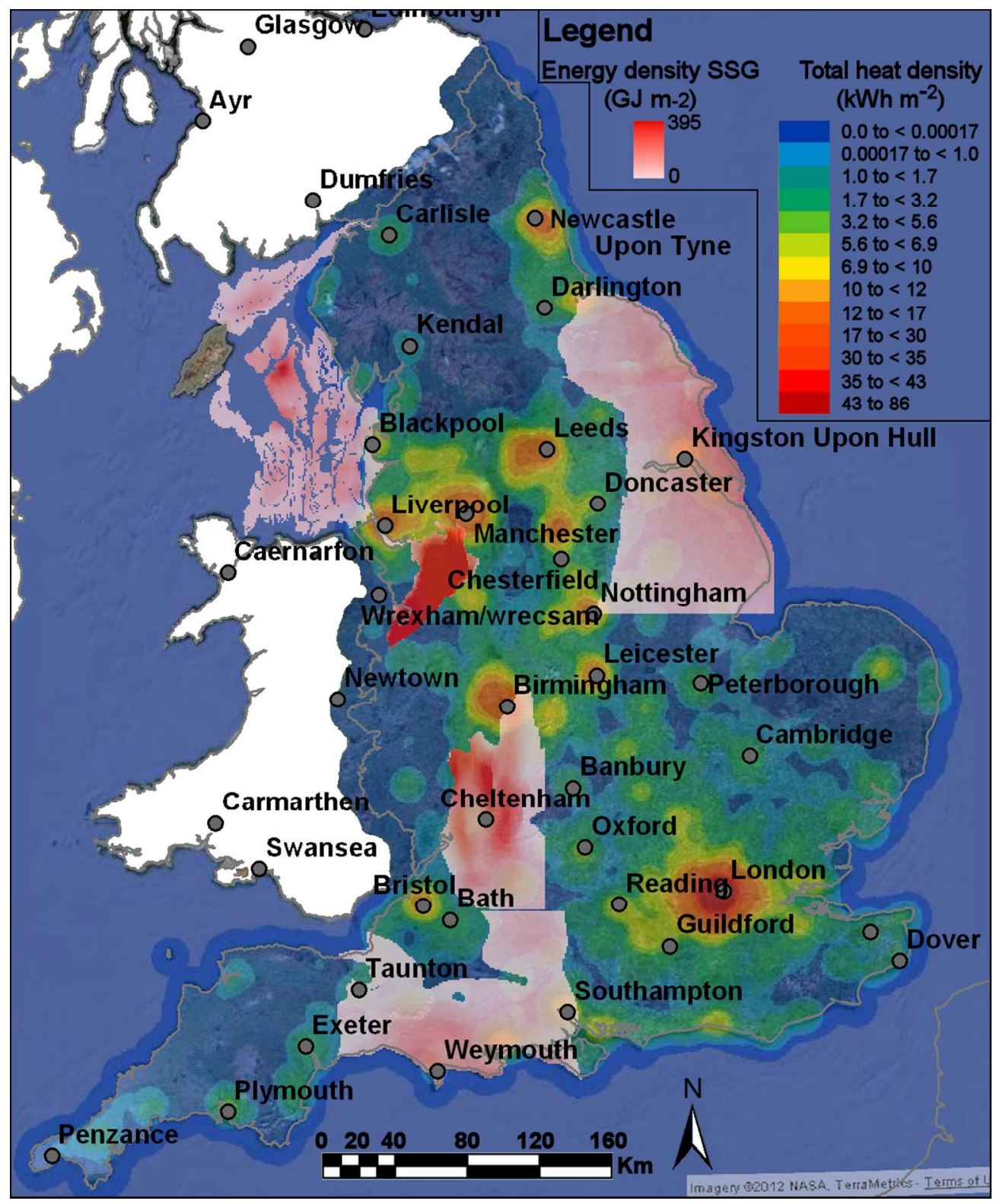

Figure 4. Heat demand map for England displayed at national scale with the heat in place (Inferred Geothermal Resource) for the Sherwood Sandstone Group as an overlay. The heat demand map is displayed on a rainbow scale as a total heat density from 86 to $0.00017 \mathrm{kWh} \mathrm{m-2}$. The heat in place is displayed as an energy density in GJ m-2 with 30\% transparency to allow the heat demand map to be seen in areas with heat in place.

$157 \times 190 \mathrm{~mm}(200 \times 200 \mathrm{DPI})$ 


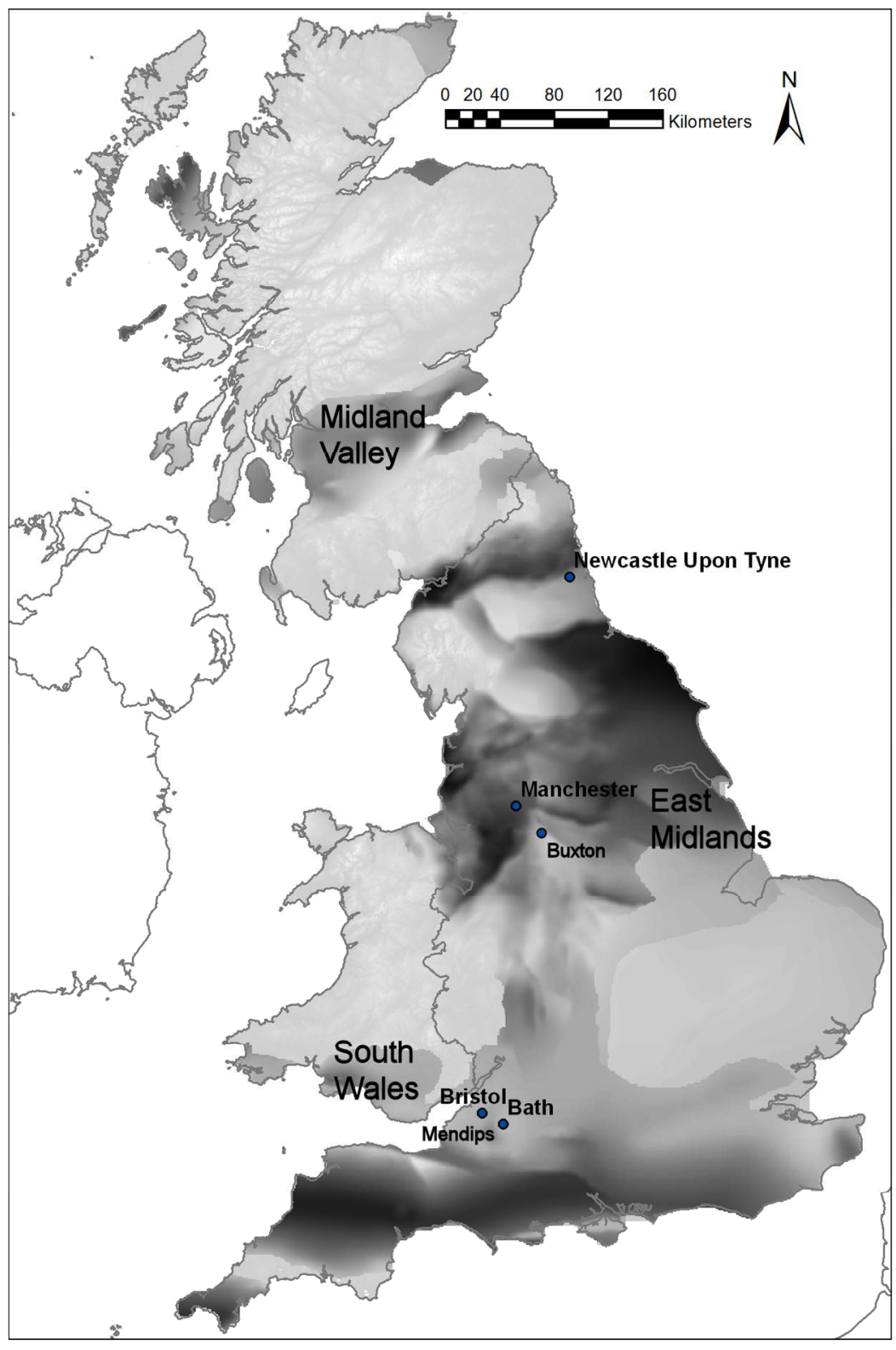

Figure 5. Distribution of Carboniferous rocks in Britain displayed as a regional map of depth to base Carboniferous. Darker areas show the greatest depths. $175 \times 264 \mathrm{~mm}(200 \times 200 \mathrm{DPI})$ 


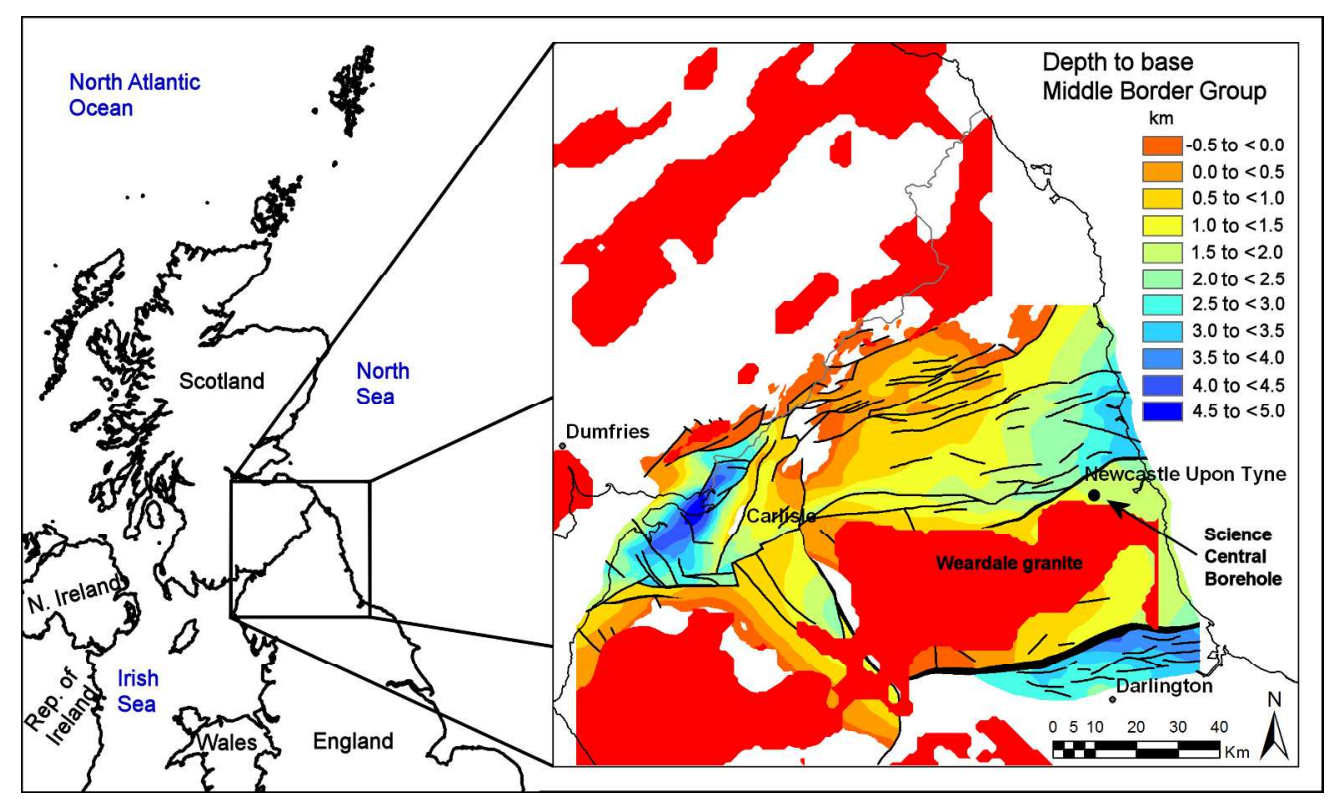

Figure 6. Location of the Science Central borehole to the south of the southerly bounding fault (the Ninety Fathom-Stublick fault zone) of the Northumberland Trough. Areas in red show where there is granite within the crust.

$327 \times 195 \mathrm{~mm}(200 \times 200 \mathrm{DPI})$ 


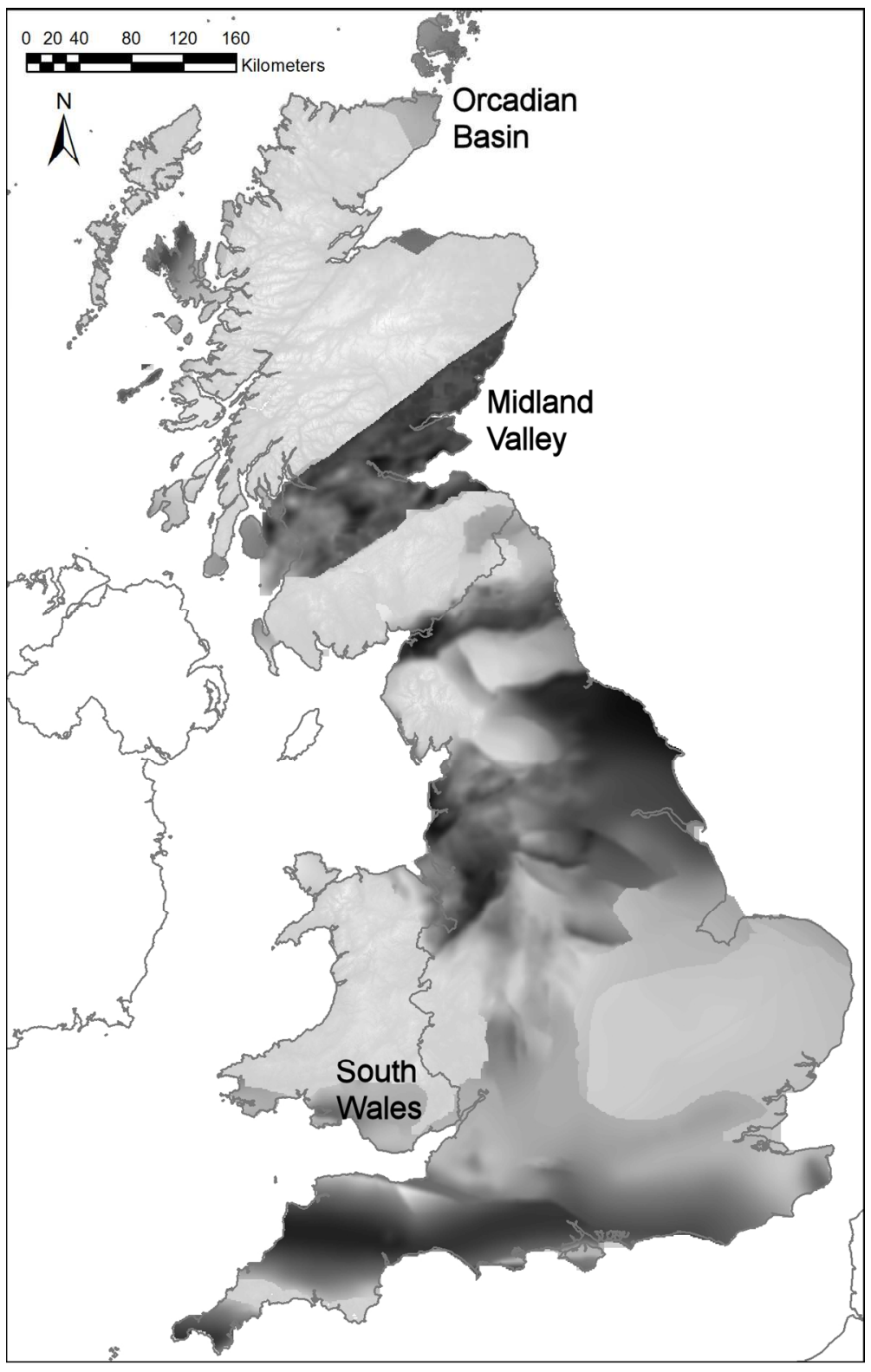

Figure 7. Distribution of Devonian rocks in Britain displayed as a regional map of depth to base Devonian. Darker areas show the greatest depths. $169 \times 267 \mathrm{~mm}(200 \times 200 \mathrm{DPI})$ 